\title{
PENINGKATKAN INTERAKSI BELAJAR SISWA SMA KELAS X DENGAN MENGGUNAKAN MODEL PEMBELAJARAN NUMBERED HEAD TOGETHER
}

\author{
Sumargiyani $^{a}$, Sri Widayati ${ }^{b}$ \\ ${ }^{a}$ Program Studi Pendidikan Matematika FKIP UAD \\ Jl. Prof. Dr. Soepomo, SH. Janturan Yogyakarta, sumargiyani04@yahoo.com \\ ${ }^{b}$ SMA Negeri 2 Bantul \\ Jl. R.A. Kartini, Trirenggo, Kec. Bantul, Bantul
}

\begin{abstract}
ABSTRAK
Model pembelajaran yang diterapkan dalam kelas merupakan salah satu komponen yang mempengaruhi hasil belajar siswa. Kurangnya interaksi belajar siswa dimungkinkan dapat berpengaruh pada rendahnya hasil belajar. Penelitian ini bertujuan untuk meningkatkan interaksi belajar pada mata pelajaran matematika materi persamaan eksponen dengan menggunakan model pembelajaran Numbered Head Together(NHT) Siswa kelas X MIA 6 SMA Negeri 2 Bantul. Penelitian ini merupakan penelitian tindakan kelas. Subjek dalam penelitian ini adalah siswa kelas X MIA 6 SMA Negeri 2 Bantul. Sedangkan objek penelitian adalah pembelajaran dengan model pembelajaran NHT pada mata pelajaran matematika pada siswa kelas X MIA 6 SMA Negeri 2 Bantul tahun ajaran 2018/2019. Penelitian dilaksanakan sebanyak 2 siklus dengan masing-masing siklus dua kali pertemuan. Data dikumpulkan dengan observasi, wawancara dan tes. Analisis data yang digunakan adalah reduksi data, display data, triangulasi dan penarikan kesimpulan. Hasil penelitian menunjukkan bahwa dengan menerapkan model pembelajaran NHT dapat meningkatan interaksi belajar siswa pada mata pelajaran matematika siswa kelas X MIA 6 SMA Negeri 2 Bantul Tahun Ajaran 2018/2019 pada materi persamaan eksponen. Hal ini dapat dilihat dari rata-rata persentase interaksi belajar pada Siklus I sebesar 74,12\% dengan kriteria (baik) meningkat pada Siklus II sebesar 79,72\% dengan kriteria (baik)
\end{abstract}

Kata Kunci : persamaan eksponen, $N H T$, interaksi belajar

\begin{abstract}
The learning model applied in the classroom is one component that affects student learning outcomes. Lack of student learning interactions is possible can affect the low learning outcomes. This study aims to improve learning interactions on mathematics subjects in the exponential equation using the Numbered Head Together (NHT) learning model of class X MIA SMA Negeri 2. This research is a classroom action research. The subjects in this study were students of class X MIA 6 SMA Negeri 2. While the object of research is learning with the NHT learning model on mathematics subjects in class X MIA 6 SMA Negeri 2in the academic year 2018/2019. The study was conducted in 2 cycles with each cycle two meetings. Data was collected by observation, interviews and tests. Analysis of the data used is data reduction, data display, triangulation and conclusion. The results showed that by applying the NHT learning model can improve student learning interactions on mathematics subjects in class X MIA 6 SMA Negeri 2Academic Year 2018/2019 on exponential equation material. This can be seen from the average percentage of learning interactions in Cycle I of $74.12 \%$ with criteria (good) increased in Cycle II amounting to $79.72 \%$ with criteria (good)
\end{abstract}

Keywords: exponent equation, NHT, learning interaction 


\section{Pendahuluan}

Belajar sebagai proses atau aktivitas dipengaruhi oleh banyak faktor. Faktor-faktor yang mempengaruhi belajar meliputi faktor intern dan faktor ekstern. (Slameto,2010:54). Guru sebagai salah satu faktor ekstern memiliki banyak pengaruh terhadap keberhasilan siswa dalam belajar di sekolah. Oleh karena itu, guru yang memiliki tugas utama mengajar, dituntut untuk menguasai strategi-strategi atau pendekatan-pendekatan dalam pembelajaran agar pelaksanaan pembelajaran yang berlangsung di kelas dapat berjalan optimal.

Pemilihan model pembelajaran dilakukan guru, sebagai suatu rencana untuk mengajarkan materi pelajaran di kelas. Pemilihan model pembelajaran dilakukan oleh guru dengan mempertimbangkan berbagai komponen. Komponen kegiatan belajar mengajar meliputi tujuan, bahan pelajaran, kegiatan belajar mengajar, metode, alat dan sumber, serta evaluasi. (Djamarah ,Syaiful Bahri \&Zain,Aswan, 2010:41).

Berdasarkan informasi dari guru mata pelajaran matematika kelas X SMA Negeri 2 Bantul, beliau belum pernah menerapkan model pembelajaran kooperatif tipe NHT dan jarang menerapkan metode pembelajaran dengan membuat siswa berdiskusi secara

Peningkatan ... (Sumargiyani) berkelompok. Oleh karena guru menerapkan model pembelajaran ekspositori sehingga kondisi selama pembelajaran berlangsung interaksi antar siswa belum berjalan secara optimal. Interaksi siswa dengan sumber belajar dapat terjadi, karena guru memanfaatkan lembar kegiatan siswa (LKS) untuk latihan soal.

Interaksi belajar mengajar adalah suatu hal yang saling melakukan aksi di dalam proses belajar mengajar yang di dalamnya ada suatu hubungan antara siswa dan guru untuk mencapai suatu tujuan. Interaksi dapat dilakukan antara siswa dengan siswa, interaksi siswa dengan guru, dan interaksi siswa dengan sumber belajar (Inah,Ety Nur,2015). Interaksi dalam proses pembelajaran di kelas dilakukan untuk menciptakan suatu kondisi edukatif yang nyaman,aman dan tenang menuju efisiensi, afektifitas dan optimalisasi dalam proses pembelajaran. (Muttaqin,Arief. 2016).

Penerapan model pembelajaran kooperatif NHT akan membuat siswa lebih aktif selama proses pembelajaran. Selain membuat lebih aktif juga hasil belajar matematika yang diperoleh siswa meningkat. (Maisyarah,2015). Dari hasil penelitian yang telah dilakukan Alie, Nurhayati Husain (2013) juga menunjukkan bahwa dengan 
menerapkan model pembelajaran kooperatif NHT dapat meningkatkan hasil belajar siswa. Selain meningkatkan hasil dengan model pembelajaran NHT juga dapat meningkatkan aktivitas belajar, seperti hasil penelitian yang dilakukan oleh Baskoro,Febri dkk (2013). Model pembelajaran NHT ini dapat diterapkan dalam mengajarkan matematika, karena berdasarkan hasil penelitian yang dilakukan Sumargiyani (2015) model pembelajaran kooperatif NHT lebih efektif dibanding model pembelajaran konvensional (model ekspositori) untuk mengajarkan matematika. Model pembelajaran NHT merupakan suatu model pembelajaran berkelompok dengan masing-masing anggota bertanggung jawab atas tugas kelompoknya (Shoimin,Aris, 2014:108).

Model pembelajaran NHT telah memberi kesempatan kepada siswa untuk saling berbagi gagasan dan mempertimbangkan jawaban yang paling tepat. (Huda,Miftahul.2014:203)

Berdasarkan uraian di atas, menurut hemat penulis dilakukan suatu penelitian yang bertujuan untuk meningkatkan interaksi belajar matematika dengan menerapkan model pembeajaran kooperatif NHT pada materi persamaan eksponen siswa kelas $\mathrm{X}$ MIA 6 SMA negeri 2 Bantul tahun ajaran $2018 / 2019$.

\section{Metode Penelitian}

Kegiatan penelitian ini bertempat di SMA Negeri 2 Bantul Tahun Ajaran 1018/2019. Kegiatan yang dilaksanakan dalam rangka penugasan dosen di sekolah ini, mengambil subjek penelitian siswa kelas $\mathrm{X}$ MIA 6 SMA Negeri 2 Bantul Tahun Ajaran 2018/2019 sebanyak 30 siswa. Obyek penelitian ini adalah keseluruhan proses pembelajaran dengan model pembelajaran kooperatif tipe $N H T$, dan interaksi belajar siswa dalam mata pelajaran Matematika wajib. Jenis penelitian yang dilakukan Penelitian Tindakan Kelas (PTK) ini mencakup empat langkah yakni : planning, acting, observing dan reflecting (Mulyasa, H.E.2011:112). Penelitian tindakan kelas ini mengambil bentuk penelitian kolaborasi, yakni dosen pendidikan matematika FKIP UAD bekerjasama dengan guru mata pelajaran matematika SMA Negeri 2 Bantul tergabung dalam satu tim untuk melakukan penelitian dengan tujuan untuk menjawab permasalahan di kelas dan untuk memperbaiki praktek-praktek dalam pembelajaran. Prosedur penelitian tindakan kelas dilaksanakan dalam dua siklus dengan masing-masing siklus 2 kali pertemuan. Instrumen penelitian yang digunakan dalam penelitian ini adalah: (1). Lembar Kerja Siswa 
(LKS) berisi materi persamaan eksponen, contoh soal dan soal-soal latihan, (2). Pedoman wawancara siswa untuk pedoman ketika mewawancari siswa guna memperoleh data interaksi belajar siswa, dan (3) Lembar observasi, yang berisi catatan yang menggambarkan bagaimana interaksi belajar yang dilakukan siswa selama pembelajaran di kelas. Format lembar observasi berbentuk pilihan ganda dengan dua alternatif jawaban (ya dan tidak) dan disertai beberapa catatan yang ditemukan di lapangan. Teknik pengumpulan data yaitu : wawancara dan observasi. Analisis data yang dilakukan meliputi : analisis data observasi, reduksi data, triangulasi, display data, dan penarikan kesimpulan. Indikator keberhasilan penelitian ini apabila interaksi belajar yang diperoleh dengan kriteria minimal baik.

\section{Hasil dan Pembahasan}

Kegiatan pembelajaran terdiri atas dua siklus. Pada masing-masing siklus terlaksana dalam dua kali pertemuan. Hal ini dilakukan dengan harapan tindakan yang dilakukan dalam pembelajaran memperoleh hasil interaksi belajar minimal baik. Setiap tindakan dilakukan dengan menerapkan model pembelajaran kooperatif tipe NHT, dan pada setiap pertemuan dilakukan suatu tindakan untuk memperbaiki kekurangankekurangan yang ada di pertemuan sebelumnya, sehingga tindakan lebih mengarah ke peningkatan interaksi belajar siswa dan pemahaman siswa pada materi pelajaran yang disampaikan.

Selama pelaksanaan pembelajaran berlangsung, telah diamati interaksi belajar siswa. Pengamatan dilakukan oleh tiga orang observer, dengan masing-masing observer mengamati dua kelompok yang masingmasing kelompok lima orang siswa. Hasil interaksi belajar siswa selama dua siklus diperoleh hasil berikut ini. 
Tabel 1. Hasil Interaksi Belajar Siswa Siklus 1 dan Siklus 2

\begin{tabular}{lcc}
\hline \multicolumn{1}{c}{ Indikator/aspek } & \multicolumn{2}{c}{ Siklus } \\
\hline A. Interaksi siswa dengan Guru & 1 & 2 \\
1. Bertanya pada Guru & $76,67 \%$ & $83,33 \%$ \\
2. Menjawab pertanyaan Guru & $90,00 \%$ & $90,00 \%$ \\
3. Memanfaatkan Guru sebagai narasumber & $66,67 \%$ & $86,67 \%$ \\
4. Memanfaatkan Guru sebagai fasilatator & $73,33 \%$ & $76,67 \%$ \\
B. Interaksi siswa dengan siswa & $96,67 \%$ & $93,33 \%$ \\
1. Bertanya pada teman dalam kelompok. & $98,33 \%$ & $90,0 \%$ \\
2. Menjawab pertanyaan teman dalam satu kelompok. & $23,33 \%$ & $50,00 \%$ \\
3. Bertanya pada teman dalam kelompok lain. & $20,00 \%$ & $53,33 \%$ \\
4. Menjawab pertanyaan teman dalam kelompok lain. & & \\
C. Interaksi siswa dengan sumber belajar & $98,33 \%$ & $100,00 \%$ \\
1. Membaca materi yang ada di sumber belajar & $93,33 \%$ & $83,33 \%$ \\
2. Membaca latihan -latihan soal yang ada di sumber & \\
belajar & $66,67 \%$ & $66,67 \%$ \\
3. Membaca sumber belajar untuk menjawab soal-soal & $74,12 \%$ & $79,72 \%$ \\
\hline
\end{tabular}

Data hasil interaksi belajar di atas jika dikriteriakan atau dikategorikan dengan menggunakan Tabel 2, maka diperoleh interaksi belajar siswa pada Siklus 1 dan Siklus 2 masing-masing dengan kriteria baik.

Tabel 2. Kualitatif Hasil Lembar Obsevasi

\begin{tabular}{cc}
\hline Persentase & Kriteria \\
\hline $80 \%<\mathrm{P} \leq 100 \%$ & Sangat Baik \\
$60 \%<\mathrm{P} \leq 80 \%$ & Baik \\
$40 \%<\mathrm{P} \leq 60 \%$ & Cukup \\
$20 \%<\mathrm{P} \leq 40 \%$ & Kurang \\
$0 \% \leq \mathrm{P} \leq 20 \%$ & Kurang sekali \\
\hline
\end{tabular}

\section{Siklus 1}

Sebelum memulai pembelajaran guru telah melakukan persiapan dengan menyusun : Rencana Pelaksanaan Pembelajaran (RPP), Lembar observasi interaksi belajar siswa, pedoman wawancara, dan LKS dengan pokok bahasan persamaan eksponen.

Di dalam pelaksanaan pembelajaran, guru memotivasi siswa untuk aktif belajar dan aktif selama proses pembelajaran. Guru menyuruh siswa duduk sesuai kelompoknya dan memakai nomer yang telah dibagikan. Guru melaksanakan pembelajaran sesuai dengan langkah - langkah model pembelajaran kooperatif NHT. Pelaksanaan pebelajaran ini telah mendapatkan respon yang positip dari siswa, karena berdasarkan hasil wawancara siswa mengatakan bahwa mereka dapat terlibat aktif dengan diterapkannya model pembelajaran NHT dan 
dengan berkelompok dapat bertanya juga dapat mengerjakan soal bersama-sama.

Dari hasil observasi pada Siklus I pertemuan pertama, diperoleh hasil interaksi siswa dengan guru sudah baik. Ketika guru mengajukan pertanyaan sebagian besar siswa menjawab. Sebagian siswa tidak menjadikan guru satu-satunya narasumber, karena siswa ada yang memilih teman yang pandai sebagai narasumber. Interaksi siswa dengan kelompok lain masih rendah, hal ini dikarenakan siswa dalam mengerjakan soal latihan lebih sibuk mengerjakan dengan anggota kelompoknya sendiri dan apabila mengalami kesulitan langsung bertanya dengan guru, bukan bertanya dengan kelompok lain. Interaksi siswa dengan sumber belajar, dimana sumber belajar digunakan untuk acuan menjawab soal-soal latihan masih rendah. Hal ini dikarenakan, siswa sudah paham ketika guru menjelaskan cara mengerjakan soal di papan tulis sehingga tidak perlu lagi melihat contoh-contoh penyelesaian soal yang ada di LKS.

Hasil observasi Siklus I Pertemuan 2 telah ditemukan : sebagian siswa memanfaatkan guru sebagai fasililator dalam mengerjakan soal-soal latihan; sebagian siswa tidak bertanya dengan kelompok lain dalam mengerjakan soal latihan, karena mereka sudah bisa mengerjakan sendiri dengan teman

Peningkatan ... (Sumargiyani) sekelompoknya. Sebagian besar siswa sudah bisa mengerjakan sendiri karena mereka mengatakan sudah paham, dan tidak memerlukan bantuan teman lain.

Data hasil observasi telah diperkuat dengan data hasil wawancara ke siswa, yang secara garis besarnya diproleh hasil : guru dijadikan sebagai sumber ilmu; siswa menjawab pertanyaan guru agar siswa mengetahui jawaban yang disampaikan si benar atau salah; siswa menjawab pertanyaan guru sebagai sebagai latihan berbicara ; guru dijadikan narasumber karena ketika bertanya ke guru ditanggapi oleh guru secara ramah ; guru sebagai fasilitator karena fasilitas yang guru berikan dapat menunjang pembelajaran dan pembelajaran nampak menarik; dapat bertanya dengan teman karena temannya temannya yang paham dapat menjelaskan dengan mudah; siswa mau membantu teman yang bertanya, karena siswa itu berprinsip dengan membantu orang lain pahalanya besar ; siswa ketika membaca materi LKS sebagai sumber belajar belum sepenuhnya paham sehingga siswa tetap memerlukan penjelasan ; siswa membaca latihan-latihan soal yang ada di sumber belajar agar paham materi eksponen.

Sebelum melanjutkan ke tahap Siklus 2, dilakukan refleksi Siklsu 1 antara guru dengan tiga orang observer dan dua orang 
siswa yang diambil secara acak, dan diperoleh hasil : Sebagian besar siswa tidak melakukan tanya jawab dengan kelompok lain karena mereka sudah bisa mengerjakan sendiri dengan teman satu kelompoknya; siswa sudah aktif tetapi perlu diaktifkan lagi selama pembelajaran; siswa yang memiliki kemampuan kurang, agar lebih diperhatikan; pembelajaran dengan berkelompok membuat siswa lebih enak, lebih mudah, dan bisa saling berinteraksi; pembelajaran NHT membuat siswa lebih siap, karena sewaktu-waktu disuruh maju lebih siap dan tidak bikin ngantuk; dan untuk pertemuan selanjutnya perlu diubah anggota kelompoknya.

\section{Siklus 2}

Kekurangan-kekurangan yang ditemukan di Siklus 1 telah diperbaiki pada kegiatan Siklus 2. Tahap perencanan, Pada kegiatan perencanaan siklus 2 yang dilakukan membuat : LKS dengan materi persamaan eksponen, lembar observasi, RPP, pedoman wawancara, memotivasi siswa supaya berani bertanya dengan memancing beberapa pertanyaan ke masing-masing kelompok ataupun secara individual dan membantu siswa yang masih mengalami kesulitan dalam memahami materi persamaan eksponen.

Tahap tindakan, pada tahap tindakan ini peneliti mengubah posisi tempat duduk siswa, yang pada awalnya siswa duduk di belakang diubah duduk di depan dan sebaliknya. Pelaksanaan pembelajaran masih tetap menggunakan model pembelajaran NHT dan materi yang disampaikan melanjutkan materi sebelumnya, yaitu persamaan eksponen.

Observasi dilaksanakan selama kegiatan pembelajaran berlangsung. Dari hasil observasi telah terjadi peningkatan interaksi belajar siswa. Siswa sudah mulai berani bertanya pada guru apabila ada materi pelajaran yang belum dipahaminya. Siswa yang belum paham dengan materi yang dipelajarinya tidak langsung bertanya dengan guru, tetapi sudah mulai bertanya dengan teman satu kelompoknya. Siswa mau menjawab pertanyaan yang disampaikan guru. Siswa sudah memanfaatkan guru sebagai narasumber untuk mengetahui penjelasan dari materi yang dibahas juga dipergunakan sebagai narasumber untuk menjawab pertanyaan dari soal-soal latihan yang mereka anggap sulit.

Siswa dapat berinteraksi dengan teman satu kelompoknya dan bekerjasama, siswa tidak bertanya dengan guru karena sudah bertanya dengan teman dan memperoleh jawaban dari teman, siswa merasa lebih nyaman bertanya dengan teman. Siswa bertanya ke guru apabila mereka tidak paham dengan materi yang sedang dipelajari dan temannya juga tidak bisa membantu 
menjelaskan materi tersebut. Kerjasama dalam kelompoknya sudah berjalan semakin baik.

Siswa setuju dengan diterapkannya model pembelajaran kooperatif NHT karena menjadikan siswa kreatif dan dapat berinteraksi dengan baik Model pembelajaran NHT ini menjadikan pembelajaran berjalan lebih efektif dan menyenangkan dan materi mudah diterima secara jelas, interaksi belajar antara siswa dengan guru dapat berjalan baik. Interaksi antar siswa dapat berjalan dengan baik dan dengan adanya interaksi antar siswa menjadikan siswa tidak bersifat individual. Dalam satu kelompok, antar siswa telah saling berdiskusi dalam menyelesaikan soal soal yang diberikan.

Refleksi yang diperoleh dari pelaksanaan pada Siklus 2 ini, sebagian besar siswa sudah berinteraksi belajar dengan baik dan terjadilah komunikasi dua arah. Komunikasi antar kelompok kurang dapat berjalan dikarenakan diskusi yang dilakukan di dalam kelompok sudah berjalan dengan sangat baik, sehingga kurang membutuhkan interaksi dengan kelompok lain. Siswa sudah dapat memahami materi dengan penjelasan dari guru dan kelompoknya sendiri, dan sebagian besar siswa memanfaatkan LKS sebagai sumber belajar untuk memahami materi dan latihan soal.
Untuk peningkatan per indikator interaksi belajar dapat disajikan dalam bentuk grafik berikut ini

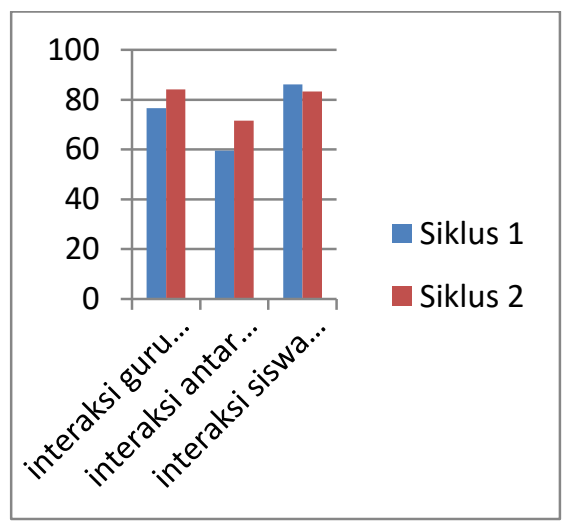

Gambar 1. Grafik Persentase Interaksi Belajar siswa per indikator pada Siklus I dan Siklus II

Dari grafik di atas, terlihat indikator interaksi guru dengan siswa telah mengalami peningkatan, begitu juga interaksi antar siswa. Untuk indiktor interaksi siswa dengan sumber belajar, mengalami penurunan karena pada aspek siswa membaca soal - soal latihan dari LKS sebagian siswa tidak melakukan, hal ini dikarenakan ketika siswa membaca langkah-langkah penyelesaian soal-soal latihan di LKS mereka tidak paham sehingga lebih memilih langsung bertanya pada guru.

Apabila dilihat di Grafik 2 dari Siklus 1 ke Siklus 2 interaksi belajar siswa 
telah mengalami kenaikan, meskipun masih dalam kriteria baik.

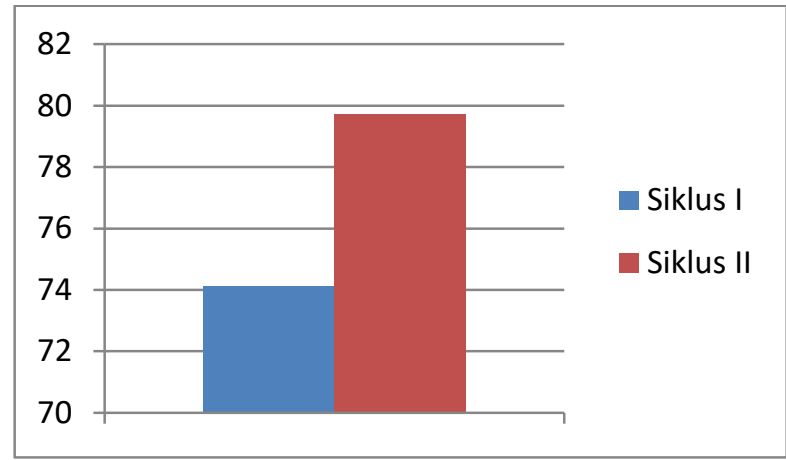

Gambar 2. Grafik Interaksi Belajar Siswa Per Siklus.

Dari hasil penelitian ini dapat dikatakan bahwa dengan penerapan model pembelajaran kooperatif tipe NHT dapat meningkatkan interaksi belajar siswa pada materi persamaan eksponen.

\section{Kesimpulan}

Hasil penelitian menunjukkan bahwa model pembelajaran NHT dapat meningkatan interaksi belajar siswa pada mata pelajaran matematika siswa kelas $\mathrm{X}$ MIA 6 SMA Negeri 2 Bantul Tahun Ajaran 2018/2019 pada materi persamaan eksponen. Hal ini dapat dilihat dari rata-rata persentase interaksi pada Siklus I sebesar $77,21 \%$ dengan kriteria (baik) meningkat pada Siklus II sebesar $77,96 \%$ dengan kriteria (baik). Pembelajaran dengan menerapkan model pembelajaran NHT mendapat respon yang positip dari siswa.

\section{Pustaka}

Alie, Nurhayati Husain, 2013. “Penggunaan Model Pembelajaran Kooperatif Tipe NHT Untuk Meningkatkan Hasil Belajar Siswa Kelas X2 SMA Neg. 3 Gorontalo Pada Materi Jarak Pada Bangun Ruang”.Jurnal:Enthropi.Vol.08.No : 01. hal.583-592

Baskoro,Febri; Saputro, Sulistyo; Hastuti, Budi,2013. 'Upaya Peningkatan Aktivitas Dan Prestasi Belajar Dengan Model Pembelajaran NHT (Numbered Head Together) Dilengkapi LKS Pada Materi Termokimia Siswa Kelas XI IPA-3 SMA Negeri 6 Surakarta”.Jurnal: Pendidikan Kimia Vol. 2, No. 2. hal. 85-91

Djamarah, Syaiful Bahri \& Zain, Aswan, 2010.Strategi Belajar Mengajar. Jakarta: Rineka Cipta

Huda,Miftahul.2014.Penelitian Tindakan Kelas :Teori dan Praktik. Yogyakarta : Pustaka Pelajar

Inah,Ety Nur, 2015. "Peran Komunikasi Dalam Interaksi Guru Dan Siswa". Jurnal:AlTa'dib Vol. 8 No. 2, Juli-Desember. hal: $150-167$

Maisyarah.2015. "Meningkatkan Hasil Belajar Dan Aktivitas Siswa Melalui Model Pembelajaran Kooperatif Tipe NHT". Jurnal :Math Didactic. Vol. 1, No. 2, Mei -Agustus 2015. hal: 125131.

Mulyasa,H.E. Alie, Nurhayati Husain, 2013. Praktik Penelitian Tindakan Kelas.Bandung: PT Remaja Rosdakarya Muttaqin,Arief.2016."Interaksi Pengajaran Yang Edukatif".

https://arifmuttaqinblog.wordpress.com/20 16/04/11/interaksi-pengajaran-yangedukatif/ diakses tanggal 20 Oktober 2018 pukul 06.08.

Riduwan,2011.Dasar-dasar Statistika. Bandung: 
Alfabeta.

Shoimin,Aris, 2014. 68 Model Pembelajaran Inovatif dalam Kurikulum 2013. Yogyakarta: Ar-Ruzz Media

Slameto.2003. Belajar dan Faktor-faktor Yang Mempengaruhinya. Jakarta : Rineka Cipta

Sumargiyani,2015.'Efektivitas Model Pembelajaran NHT terhadap hasil belajar matematika SMP". Jurnal :AdMathEdu Vol. 5. No:2 hal: 193-202.

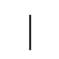

